Agenda

Empowering women for gender equity

ISSN: 1013-0950 (Print) 2158-978X (Online) Journal homepage: https://www.tandfonline.com/loi/ragn20

\title{
Women in detention in Africa: A review of the literature
}

\section{Marilize Ackermann}

To cite this article: Marilize Ackermann (2015) Women in detention in Africa: A review of the literature, Agenda, 29:4, 80-91, DOI: 10.1080/10130950.2015.1122345

To link to this article: https://doi.org/10.1080/10130950.2015.1122345

曲 Published online: 14 Jan 2016.

Submit your article to this journal $₫$

LII Article views: 350

Q View related articles $\sqsubset$

View Crossmark data ¿ 


\title{
Women in detention in Africa: A review of the literature
}

\author{
Marilize Ackermann
}

\section{abstract}

\begin{abstract}
Women in prison in Africa experience compounded discrimination due to gender and poverty. Structural inequality results in women being poorly educated, having reduced access to economic resources and legal processes. Women often remain in pre-trial detention since they are unable to afford bail or fines. A significant number of women in prison are mothers and often, the sole or primary caregiver of children prior to detention. The true impact of female detention is felt by children who are imprisoned with their mothers, or who remain alone on the outside. In addition to the profound social and economic impact on families, women in prison are affected by a number of gender-related issues, including reproductive health needs, mental health disorders connected to prior experiences of violence, abuse and substance abuse, and heightened vulnerability to sexual abuse and harassment in detention. The literature review looks at the reasons for female imprisonment in a number of African countries, and explores the unique needs of women in detention, against the backdrop of the international detention framework, and particularly, the United Nations Rules for the Treatment of Women Prisoners and Non-Custodial Measures for Women Offenders (the Bangkok Rules).
\end{abstract}

\section{keywords}

women, prison, Africa, pre-trial, detention

This briefing is based on a literature review commissioned by the Civil Society Prison Reform Initiative (Dulla Omar Institute, University of the Western Cape) and was made possible with funding from the Open Society Institute. The full report is available at http://cspri.org.za/publications/researchreports/WomenInPreTrialDetention_V2.pdf/ view

\section{Introduction}

According to recent estimates, around 700,000 women and girls are detained around the world (Walmsley 2015:1) representing between $2 \%$ and $9 \%$ of most countries' prison populations (Penal Reform

Agenda 106/29.4 2015

ISSN 1013-0950 print/ISSN 2158-978X online

(C) 2016 Marilize Ackermann

http://dx.doi.org/10.1080/10130950.2015.1122345
International, 2015:12). The United Nations (UN) Special Rapporteur on Extreme Poverty and Human Rights frames the particular situation of women in prison as follows:

"In this respect, women are particularly vulnerable to penalization measures. Due to structural discrimination, women have less representation in structures of power and therefore are disproportionately disadvantaged in their dealings with State authorities and less able to claim their rights. Often penalization measures have a much more onerous impact on women than men, given that women are overrepresented among the poor, have less access to education,

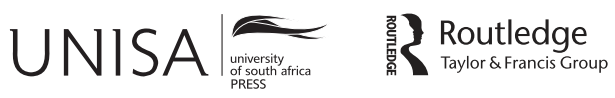
pp. $80-91$ 
employment and economic resources, and assume the principal burden of care and domestic work" (UN Special Rapporteur on Extreme Poverty, 2011:5)

Adopted in 2010, the UN Rules for the Treatment of Women Prisoners and Non-Custodial Measures for Women Offenders (Bangkok Rules) acknowledges specific concerning aspects of female detention that include: the social, economic and emotional impact of imprisonment on the children of detainees; gender-related health issues, including reproductive health needs, breast- and cervical cancer screening, mental health disorders related to prior experiences of abuse and domestic violence, substance misuse and increased vulnerability to sexual abuse and harassment.

The review assessed some of these challenges as documented in a number of African countries to get a sense of compliance with international standards, and through looking at reasons for detention, to understand the causes of some of the particular needs. In particular, it looked at the situation of women with children, genderrelated health aspects and mental health. The review draws on practices documented in a number of African states including: South Africa, Malawi, Zimbabwe, Kenya, Zambia, Sierra Leone and Ghana. The choice of states is focussed around the countries in which the Civil Society Prison Reform Initiative (CSPRI) has previously conducted research. Due to the paucity of inclusive information on the aspects of female detention discussed, the article does not have a focus on any particular country but rather looks at the available literature to exemplify the application of the Bangkok Rules on three of the main issues faced by women in prison.

the Bangkok Rules represent a progressive step towards advancing basic human rights in detention

\section{International legal framework}

The UN Standard Minimum Rules for the Treatment of Prisoners of 1955 (UNSMR) is the key text in the detention framework, yet it affords little attention to gender-related challenges faced by women in prison.
Provisions relevant to gender distinctions are limited to the separation of male and female detainees, the accessibility of medical services to pregnant detainees and the imprisonment of children with their mothers (UN General Assembly, 1955 - Rules $8,23 \& 53)$

In the context of the development of a gender-specific approach to detention, the United Nations Congress on the Prevention of Crime and the Treatment of Offenders effectively served as the main forum at which the recognition of the needs of women in detention was addressed and promoted. The issue was debated at each of the five-yearly Congresses, from the Sixth Congress held in 1980 to the Eleventh Congress in 2005 (Barzano, 2013). At the Tenth Congress, member states adopted the Vienna Declaration on Crime and Justice: Meeting the Challenges of the 21st Century (UN General Assembly, 2001) and thereby marking a commitment to take into account and address, not only within the United Nations crime prevention and criminal justice programme, but also at domestic level, any disparate impact of programmes and policies on women, and to develop recommendations relevant to the unique needs of female detainees (UN Economic and Social Council, 2010). In 2003 and 2008, the United Nations General Assembly called on states to acknowledge the problems faced by women in detention and to consider the impact of imprisoning women with child care duties, as well as babies or small children incarcerated with mothers (UN General Assembly, 2003; UN General Assembly, 2008). At the 18th session of the Commission on Crime Prevention and Criminal Justice in 2009, a resolution submitted by the Government of Thailand was adopted, acknowledging as a premise to the Bangkok Rules that prison facilities are built primarily for males and the necessity to specifically address and accommodate female detainees'needs (Penal Reform International and Quaker United Nations Office, 2011).

With the adoption of the UN Rules for the Treatment of Women Prisoners and Noncustodial Measures for Women Offenders in 2010 (Bangkok Rules), issues faced by women in prisons gained formal recognition in international human rights law. Although a non-binding instrument, the Bangkok Rules represent a progressive step towards 
advancing basic human rights in detention and access to justice for women deprived of their liberty. Not only does it recognise women as a vulnerable group within the criminal justice system, but observes that female offenders generally pose a low risk to others. This is aligned with the observation that violent crime is often committed in response to prolonged victimisation or abuse directly preceding arrest (UN Special Rapporteur on Violence against Women, 2013) and supports the argument in favour of the use of non-custodial measures. Through identifying the pre-trial detention phase as a period during which the risk of abuse and ill treatment of female detainees may be heightened, the Bangkok Rules encourage preventative practices.

In addition to the Bangkok Rules, there are a number of instruments of international soft law which govern detention. According to the Body of Principles for the Protection of All Persons under any Form of Detention or Imprisonment, special arrangements made for women, especially pregnant women, do not constitute discrimination but are aimed at attaining gender equality in prisons (UN General Assembly, 1988 Principle 52). The UN Standard Minimum Rules for Non-Custodial Measures, also known as the Tokyo Rules, speak to the need to develop a non-institutionalised approach to the treatment of offenders and call on states to employ non-custodial measures at the earliest possible stage (UN General Assembly, 1991). Whilst the latter instrument is gender-neutral in its application, it resonates with the cases of women detained for non-violent offences and those who are deemed to pose a low risk of public endangerment.

Under treaty law, the UN Convention on the Rights of the Child (UNCRC) places a duty on State Parties to consider the child's best interest, as well as the child's right to family unity, before separating him or her from a parent (UN General Assembly, 1989 - Articles 5, 8, 9 \& 16) This becomes a relevant consideration in the context of mothers separated from their children through imprisonment.

At regional level, Article 30 of the African Charter on the Rights and Welfare of the Child (ACRWC) reflects State Parties' duty to apply protective measures to children of imprisoned mothers (African Commission on Human and Peoples' Rights, 1979). In cases where the offender is pregnant or the mother of young children, non-custodial sentences should be considered as a priority. No State Party should impose the death penalty on pregnant women or mothers of young children. The ACRWC (Article 30) further confirms the importance of eventual reintegration of the mother with the family and society.

\section{violent crime perpetrated in the context of a domestic relationship was prevalent amongst women in prison}

\section{Reasons for female imprisonment}

\section{Female criminality explored in various African countries}

Internationally, crimes perpetrated by women are frequently connected to prior abuse or domestic violence, drug abuse, or economic hardship (UN Special Rapporteur on Violence against Women, 2013; Barzano, 2013). The review attempted to explore the profile of women in prison in a number of African countries by looking at statistics and reports available through a desktop search. In some instances the reasons for imprisonment are indicative of needs they may have in prison, for example, health care in relation to drug use, or mental health care services. Perpetration of nonviolent crime would support the argument in favour of non-custodial sentencing, especially if other factors such as motherhood, or poverty are weighted in.

Conclusions drawn from statistics and reports, some produced as far back as the 1980s, were that women were imprisoned for a broad range of reasons. Across South Africa, Zambia and Malawi, prison and crime statistics indicated that violent crime perpetrated in the context of a domestic relationship was prevalent amongst women in prison. Violent crimes constitute a relatively high proportion of the offences by women in South Africa. Statistics from 2014 indicated that $45 \%$ of female detainees, including both sentenced and remand detainees, were imprisoned for economic offences, while $38 \%$ were imprisoned for aggressive crimes (Jules-Macquet, 2014). A 2012 survey of 55 female prisoners in two 
prisons in the Western Cape Province revealed murder to be the most common crime amongst respondents, followed by forgery and theft. Of the convicted offenders surveyed in the study, $42 \%$ had received some level of secondary education, $72 \%$ admitted to abusing alcohol and $30 \%$ admitted the use of drugs (Artz et al, 2012b).

A study conducted in 2003 amongst male and female prisoners in Malawi, recorded crop theft and theft of livestock as the two most common crimes, while corruption ranked third (Pelser et al, 2004). A 2004 survey of crimes committed found that of the 35 detainees identified, 19 women were detained for theft, three for manslaughter, two for assault, five for damage of property, three for unlawful wounding and three were held on miscellaneous charges, including possession of 'chamba' (cannabis) and prostitution. All the women detained for theft claimed to have been coerced to commit crime by male partners, and most incidences of violent crime were said to have been sparked by a domestic argument. The women detained on account of manslaughter all cited reasons closely related to witchcraft (avenging a deceased family member) and in each case, the victim was a close relation of the offender. Across all profiles, domestic relations played a central role. Three accounts of miscellaneous violent crimes pertained to abortion or infanticide. In each case, rejection by the father of the child was cited as a motivating factor. None of the offenders were intoxicated during the commission of their crime. All detainees were mothers (Burton et al, 2005). A second survey of 69 female detainees conducted around the same time in three Malawian prisons, Zomba Central Prison, Maulla Prison and Chichiri Maximum Security Prison, found that in 34 cases out of 69 , murder was the most common crime $(49 \%)$, with theft ranking second (eight cases). Twea's (2004) research on Malawian women prisoners found that murder was commonly motivated by witchcraft-related reasons, or involved the killing of children by mothers.

many offences were connected to the manner by which women earned their livelihood

A 1988 study of 81 female detainees (40 pre-trial and 41 convicted detainees) conducted across six Zambian prisons showed that $65 \%$ of detainees were held for violent crimes such as murder, manslaughter and assault. Most of the violent crimes were related to domestic quarrels. Theft was the second most common offence. More than $50 \%$ of the detainees were illiterate (Sakala, 1988).

A survey of 200 female detainees in Kenya's Langata prison in Nairobi in 1999 indicated that offenders had mostly committed petty crimes such as loitering with the intent to engage in prostitution, the brewing of spirits, hawking without licenses, petty thefts of property and possession of 'bhang' (cannabis). It appeared that many offences were connected to the manner by which women earned their livelihood and it was found that the crimes committed had strong links to poverty (Oketch, 1999). Similar patterns emerged from a 1998 survey of six prisons in Botswana, where the majority of women were convicted for violating trade and liquor regulations, followed by drug-related and property offences. Reportedly, women in prison were predominantly poor, young and uneducated and had suffered high levels of prior victimisation, substance misuse and mental disorders (Modie-Moroka, 2003; Botswana Police Service, Weekly crime reports, 2011 - 2013). According to prison census statistics for Zimbabwe for 2011/12, the majority of women were held on charges of common assault, theft or fraud (Zimbabwe National Statistics Agency, 2012a; 2012b; 2012c; 2012d). The practice of proxy detention in several countries, including the Democratic Republic of the Congo (DRC), South Sudan and Sierra Leone, means that women may be imprisoned for the crimes of their husbands or sons (Human Rights Watch, 2012; Thompson and Mahtani, 2012). It is not clear how common this practice is. At November 2012 in South Sudan, most female detainees were detained for alleged adultery (Human Rights Watch, 2012). It is submitted that an understanding of the reasons for imprisonment would lead to greater awareness around the needs of women in detention.

\section{Protracted pre-trial detention: Poverty, debt and access to justice}

A survey of 25 sub-Saharan African countries showed that women are more 
likely than men to live in poverty in 22 of the countries (UN Women, 2011). Legal defence processes are especially inaccessible to the poor, who are often unaware of their rights in detention. Arguably, posing bail as a precondition for release implies a higher rate of pre-trial detention amongst those without means (UN Office on Drugs and Crime (UNODC), 2007). The literature confirmed that women are particularly vulnerable to remaining in pre-trial detention due to the inability to afford fines, bail, or legal representation (Townhead, 2007). According to a 2004 survey in South Africa, a third of female remand detainees who were granted bail could not afford it, compared to $7 \%$ of male prisoners (Judicial Inspectorate of Prisons, 2004). Marking an improvement in 2007, approximately a quarter of female detainees on remand was unable to afford bail (UNODC, 2008). In 2013 the Department of Correctional Services (DCS) estimated the total percentage of remand detainees (male and female) who remain in detention despite bail having been fixed, at between $15 \%$ and $20 \%$ (DCS, 2013).

A census conducted in three Kenyan prisons during 2003 found that $86 \%$ of all remand prisoners who qualified for bail remained in prison due to financial constraints (UNODC, 2011). A similar pattern was observed in Ghana where the inability of women to access legal aid and the courts contributed directly towards large numbers of women in pre-trial detention. Many women remain subject to traditional male dominance and submit to social norms that deny them their statutory entitlements to inheritance and property (Appiah, 2013). In other words, they rely on the goodwill of men for regaining their freedom. Such cultural practices have the most serious impact on uneducated and economically disadvantaged women. Of the detainees surveyed in $2013,17 \%$ were unable to afford bail (Open Society Foundations, 2013).

In Sierra Leone, gender inequality and female poverty are pervasive problems, impacting directly on women in pre-trial detention. Disparities between the genders are said to be severe and contribute to what has been referred to as an example of the 'feminisation of poverty' (Sierra Leone Truth and Reconciliation Commission, 2005). Typical conditions for release on bail include the requirement to produce two sureties, resident in the same city as the court, each of whom must produce title deeds as evidence of property ownership (Open Society Justice Initiative, 2013). Historically, women were not able to own property and poor female detainees are unlikely to have close male acquaintances who are land owners. Where monetary bail was imposed, the average amount set was 25 times the average weekly earnings of detainees (Open Society Justice Initiative, 2011). This was disproportionately high and unaffordable for most detainees.

It was concluded that poverty and economic disadvantage had a direct impact on the prolonged remand detention of women, often more so than their male counterparts.

remand prisoners who qualified for bail remained in prison due to financial constraints

\section{Issues faced by women in prison Mothers in prison}

The Special Rapporteur on Prisons and Conditions of Detention in Africa noted that whilst prison is hardly an ideal place for pregnant women and children, it is equally prejudicial to separate babies and young children from their mothers (Special Rapporteur on Prisons and Conditions of Detention in Africa, 2001).

In respect of children allowed to stay with their mothers in prison, the Bangkok Rules (UN, 2010) require the decisions to allow children to stay with their mothers in prison to be based on the best interests of the children and reiterate that children shall not be treated as prisoners (Rules $49 \& 53$ (1)). Administratively, prison authorities are required to register the number and personal details of the children of a woman being admitted to prison (Rule 3) and the Rules place an obligation on authorities to raise awareness on child development and basic training on the health care of children amongst prison staff, so they may respond to their needs accordingly (Rule 33(3)). In addition, the development and state of health of children should be monitored by specialists in collaboration with community health services (Rule 51(1)). It is stressed in Rule 51(2) that the environment provided 
for such children's upbringing shall be as close as possible to that of a child outside prison. Child care facilities should be made available to allow female detainees to participate with activities of the prison regime (Rule 42(2)). Punishment by close confinement or disciplinary segregation of pregnant women and women with children incarcerated with them, is prohibited (Rule 22).

With regards to children who do not accompany their mothers to prison, the Bangkok Rules encourage open and extended visits to mothers in prison (Rule 28). Children should only be separated from their mothers if appropriate alternative care arrangements have been made (Rule 53 (2)).

Article 30 of the African Charter on the Rights and Welfare of the Child (ACRWC) (African Commission on Human and Peoples' Rights, 1979) is of particular importance as it obliges State Parties to apply protective measures to children of imprisoned mothers. In terms of the Charter, non-custodial sentences should always be considered first if the offender is pregnant or the mother of young children, and no State Party should impose the death penalty on pregnant women or mothers of young children. The ACRWC further confirms the importance of eventual reintegration of the mother with the family and society (Article 30 ). The First General Comment adopted by the Committee of Experts on the Rights and Welfare of the Child focused on Article 30 of the African Charter and recommends that states ensure the social welfare of children of imprisoned mothers (African Committee of Experts on the Rights and Welfare of the Child 2013, General Comment, 1).

\section{$83 \%$ of female detainees in South Africa were mothers}

Across the world, the majority of female detainees are mothers, and the sole or primary caregivers of children (Townhead, 2007). In 2006, $83 \%$ of female detainees in South Africa were mothers, $42 \%$ of whom had three or more children (Sloth-Nielsen, 2005 ), and $45 \%$ were the family breadwinner prior to their imprisonment (Haffejee et al, 2006). A survey of 67 female detainees in 2008 in South Africa found that $33 \%$ of their children were under the age of six years and $34 \%$ between six and twelve years (Luyt, 2008). The South African Constitutional Court in $S \vee M$ (2007), applied the best interest-principle by determining that sentencing authorities should take into account all varied interests, especially those of children placed at risk, to determine the best interest of children who stand to be affected by the imprisonment of their primary caregiver.

The South African Correctional Services Act No 111 of 1998 (Article 20), (Republic of South Africa, 1998) permits children to be incarcerated with their mothers up until the age of two years (but no longer), or until such a time as they can be appropriately placed in alternative care by the Department of Social Development. In Zambia, children can stay with their imprisoned mothers up to the age of four years in terms of the Prison (Amendment) Act 1996 Cap 97 (Article 56) (Laws of Zambia, 1996).

In 2012, Kenya's Legal Resources Foundation reported that prisons did not have facilities such as beds or special food for children. Children did not have access to educational lessons or medical care, and children born to women in custody had difficulty obtaining birth certificates (United States Department of State, 2012). In January 2013, a day care facility for children under the age of four was opened at Kenya's only maximum-security female institution, Langata Women's Prison in Nairobi. The centre is the first of its kind and aims to provide a normal life to children incarcerated with their mothers (Craig, 2013). A report from Zimbabwe indicated that there appeared to be no budgetary allocation for post-natal care or early childhood development and women were taken to public health facilities to give birth (Law Society of Zimbabwe, 2013).

The Special Rapporteur on Prisons and Conditions of Detention in Africa noted that most African correctional systems do not take into account the importance of the mother-child relationship when designing policy for women in prison (Special Rapporteur on Prisons and Conditions of Detention, 2012). A 2008 survey of 67 sentenced female detainees in South Africa reported that $95 \%$ of respondents had lost contact with their children after imprisonment (Luyt, 2008).

Although improvements are noted in states like South Africa and Kenya, the majority of State Parties lack the resources 
and infrastructure to fully comply with the General Comment adopted by the Committee of Experts on the Rights and Welfare of the Child and appear unable to meet the standards for service provision recommended by the Bangkok Rules. Increased focus on this area is crucial to prevent disproportionate impacts of imprisonment on families.

\section{Gender-related health needs of women in prison}

In addition to the regular health hazards of detention, women have unique health concerns. Reproductive health needs related to gender are addressed under various sections of the Bangkok Rules (UN, 2010). Medical and nutritional advice and treatment should be made available to pregnant or nursing women, and their children, as should adequate and timely food, a healthy environment and regular exercise (Rule 48). The prison regime and activities should accommodate pregnant women (Rule 42 (2)). The Bangkok Rules prohibit the use of restraints during child birth (Rule 24).

Generally, female detainees have higher HIV infection rates than male prisoners. (Fazel and Baillargeon, 2011). This reflects the situation of women in society: the prevalence of HIV infection is affected by women's exposure to poverty and abuse (UN Women, 2011). A study from South Africa found that physical or sexual abuse increased women's likelihood of HIV infection by $66 \%$ (Dunkle et al, 2004). The Bangkok Rules (UN, 2010) require screening for the presence of sexually transmitted diseases (STDs) or blood-borne diseases upon admission to prison and female detainees may also be offered testing for HIV, with preand post-test counselling (Rule 6a). A 2006 ruling by the Durban High Court ordered the prioritisation of distribution of free antiretroviral treatment (ARV) treatment to prisoners and remand detainees in South Africa ( $N$ and Others $v$ The Government of the Republic of South Africa and Others, 2006). However, evidence could not be found to confirm that ARV treatment is freely and sufficiently available within other African detention facilities.

As a preventive measure, the Bangkok Rules require testing and screening of female detainees for breast- and gynaecological cancer (Rule 18). Detainees' right to access specific medical care is dependent upon the availability of the particular service to the general female public within a given country. This position is reflected in Rule 10 of the Bangkok Rules which states that gender-specific health care services in prisons must at least be equivalent to those available in the community (UN, 2010). Breast- and cervical cancer is highly prevalent amongst women in Africa (Centre for Infectious Disease Research in Zambia (CIDRZ), n.d.; Cancer Association of South Africa, n.d.). Cancer screening services are freely available at all public hospitals and through non-profit organisations such as the Cancer Association of South Africa, and it follows therefore that this service should be equally available to female prison populations. A report by the Centre for Infectious Disease Research in Zambia indicated that women in prison did not receive gynaecological, cervical, or breast cancer screening at all (Human Rights Watch, 2010). The website of CIDRZ (n.d.) reports that cervical cancer screening points are available in each province of Zambia, therefore the service should be equally available to women in Zambian prisons.

Recent legislative amendments in South Africa require a medical examination of any remand detainee who claims to be pregnant (Correctional Services Act No 111 of 1998, Article 49A) (Republic of South Africa, 1998) and obliges prisons to meet the dietary requirements of pregnant detainees as per the Department of Health's Maternal Health Guidelines in the Regulations to the Correctional Services Act (DCS, 2012) (Article 26D). A report from Zambia suggests that women's access to ante- and postnatal care detention facilities is virtually non-existent and no provision is made for HIV prophylaxis to prevent mother-to-child transmission. The nutritional value of diets provided was extremely poor and women were dependent on family members to supplement the meals (Todrys and Amon, 2011).

From the above examples it is concluded that health services in South African prisons are improving, and the wide distribution of ARV medication is commendable. However, it appears that other African states have difficulty in meeting standards of health care as set out in the Bangkok Rules. Prison health is a public health issue (UNODC, World Health Organisation (WHO) and UNAIDS, 
2006) and it is in the interest of state authorities to prevent the spread of communicable diseases and ensure the general wellbeing of women, with the eye on eventual reintegration and socioeconomic contribution to their communities.

\section{African states have difficulty in meeting standards of health care as set out in the Bangkok Rules}

\section{Mental health, prior abuse and the use of substances}

International studies suggest that women in detention are more likely to suffer some form of mental illness than their male counterparts (Watson et al, 2004) and further, that statistically, female pre-trial detainees attempt suicide more often than women in wider society and male detainees (WHO, 2007a).

Disaggregated statistics for Africa on the whole could not be found, but a survey of 206 prisoners, of which $17 \%$ were women, conducted at the Lusaka Central Prison in Zambia revealed that just over $63 \%$ of participants suffered from a mental disorder (Nseluke and Siziya, 2013). A survey of 569 female detainees in South Africa found that $16 \%$ of participants had attempted suicide and $23 \%$ reported suicidal ideation: selfharm was reported by $11 \%$ of participants and $13 \%$ were using anti-depressant medication (Haffejee et al, 2006). Legislation in South Africa requires an assessment of a sentenced offender's mental health upon admission to prison and directs DCS to provide, within its available resources, adequate health care, social and psychological services for mentally ill remand detainees (Correctional Matters Amendment Act, No 5 of 2011 - Article 49D) (Republic of South Africa, 2011).

Allegedly, prisons in Sierra Leone did not have the necessary staff, medication or facilities to deal with mental disorders among males or females (Republic of Sierra Leone Ministry of Health and Sanitation, 2012). The situation was even more dire in South Sudan, where there are no mental health facilities at all, so patients are detained in prisons (Pedersen and Muntingh, 2010). Mental illness is exacerbated by imprisonment, general public intolerance of disturbing behaviour and a lack of access to mental health treatment (World Health Organisation, 2007b). There is little doubt that there is a substantial need for mental health care services, not only to prevent suicide and self-harm but to support eventual reintegration.

In broad terms, child and adult experiences of abuse have been identified as one of the most important factors distinguishing female and male offenders (Armour, 2012). Various reports indicated high levels of gender-based violence in African states, such as Zambia, Kenya and Tanzania, implying that a significant proportion of women in African prisons were, at some point, exposed to abuse (Kishor and Johnson, 2004; World Health Organisation, 2005; The Population Council, 2008). A survey of 569 women in three prisons in Gauteng Province, South Africa, revealed that $38 \%$ of participants had experienced domestic violence in their families whilst growing up, $21 \%$ were sexually assaulted before the age of 15 , and $15 \%$ were raped before the age of 15 . Some form of abuse, including emotional abuse during their last relationship was experienced by $78 \%$ of participants. Murder was committed in $38 \%$ of these cases (Haffejee et al, 2006). Research conducted by the Gender, Health and Justice Research Unit at the University of Cape Town on the relationship between female criminality and the use of substances showed that women who were addicted to, or frequently used alcohol, were more likely to have committed violent crimes. Further, it found that drug addiction was often the result of abuse, pointing to a cycle of abuse, substance misuse and crime (Artz et al, 2012a).

It is concluded that mental health is not prioritised in African contexts. It is clear from the above that there is a need for psychosocial support to victims of abuse, and that mental health should be treated in specialised facilities, other than prisons.

\section{Conclusion}

In conclusion, women in prison in Africa are effectively exposed to compounded discrimination related to gender and poverty. Contrary to the intentions expressed by the Bangkok Rules, it appeared that children of mothers in prison are the real victims of detention, whether they are born in prison 
or left on the outside. Prison conditions in Africa are often such that women's specific health needs are not met, which not only impacts on the individual, but also on her family and larger community. The paucity of information revealed a lack of political focus and allocation of resources to understand and prevent the long-term social and economic effects of female imprisonment. It is recommended that the social and economic effects of imprisoning women who are the primary or only caregiver of young children, and/or sole breadwinners in families, be considered during sentencing and especially during the pre-trial phase. It is further recommended that children imprisoned with mothers be taken care of in line with the standards proposed under the Bangkok Rules and especially, to take steps, as far as possible, to ensure that family relations are not lost.

\section{References}

Appiah K (2013) ‘Report on access to justice: Scoping study of the Justice (Formal and Informal) Sector in Ghana', available at: http://www.starghana.org/ userfiles/files/publications/Access\%20to\%20Justice $\% 20 \% 20$ Scoping $\% 20$ Study $\% 20$ of $\% 20$ the $\% 20$ Justice \%20Sector\%20in\%20Ghana.pdf, site accessed 29 March 2014.

Armour C (2012) 'Mental health in prison: A trauma perspective on importation and deprivation, female prisoners' mental health: A special trauma case?', in International Journal of Criminology and Sociological Theory, 5, 2, 88694.

Artz L, Hoffman-Wanderer Y \& Moult K (2012a) Hard Time(s): Women's Pathways to Crime and Incarceration, Gender, Health \& Justice Research Unit, University of Cape Town, available at: http://www.ghjru.uct.ac.za/pdf/hard_times.pdf, site accessed 2 April 2014.

Artz L, Hoffman-Wanderer Y \& Moult K (2012b) Women, Crime and Incarceration: Exploring Pathways of Women in Conflict with the Law, Gender, Health \& Justice Research Unit, University of Cape Town, available at: http:// www.psppd.org.za/MediaLib/Downloads/Home/ ResearchEvidence/Women\%20Crime\%20and\% 20Incarceration.pdf, site accessed 2 April 2014.

Barzano P (2013) The Bangkok Rules: An International Response to the Needs of Women Offenders, United Nations Asia and Far East Institute, Resource Material Series No. 90, available at: http://www.unafei.or.jp/english/pdf/RS_No90/ No90_11VE_Barzano.pdf, site accessed 22 February 2014.

Botswana Police Service (2011- 2013) Police Weekly Crime Report, available at: http://www.gov.bw/ en/Ministries-Authorities/Ministries/State-Presid
ent/Botswana-Police-Service-/Divisions/Crime-Re ports/POLICE-WEEKLY-CRIME-REPORT-FROM-13 062011-TO-19062011/, site accessed 8 April 2014.

Burton P, Pelser E \& Gondwe L (2005) Understanding Offending Prisoners and Rehabilitation in Malawi, Crime \& Justice Statistical Division National Statistical Office, available at: http://www.issafrica. org/uploads/Book2005UnderstandPrisoner.PDF, site accessed 22 March 2014.

Cancer Association of South Africa (n.d.) available at: http://www.cansa.org.za/, site accessed 20 March 2014.

Centre for Infectious Disease Research in Zambia (n.d.) available at: http://www.cidrz.org/cervical-cancer/, site accessed 21 March 2014.

Craig J (2013) 'Day Care Center opens for Kenya's female prisoners', Voice of America, 24 January 2013, available at: http://www.voanews.com/ content/day-care-center-opens-for-kenyas-femaleprisoners/1589985.html, site accessed 6 November 2015.

Department of Correctional Services (2013) 'Annual Report 2012/2013', available at: http://www.dcs. gov.za/docs/landing/DCS\%20Annual\%20Report \%202012-2013.pdf, site accessed 29 March 2014.

Dunkle K, Jewkes R, Brown H, Gray G, Mclntyre J \& Harlow S (2004) ‘Gender-based violence, relationship power, and risk of HIV infection in women attending antenatal clinics in South Africa', in The Lancet, 363, 9419, 1415-21.

Fazel S \& Baillargeon J (2011) 'The health of prisoners', in The Lancet, 377: 956-65, available at, http://download.thelancet.com/pdfs/journals/lancet/ PIIS0140673610610537.pdf?id=aaaF3NsBHUVjP8y AxvLtu, site accessed 21 March 2014.

Haffejee S, Vetten L \& Greyling M (2006) Violence and Abuse in the Lives of Women and Girls Incarcerated at Three Gauteng Women's Prisons, Johannesburg: Centre for the Study of Violence and Reconciliation Gender Programme, Research Brief, No. 3, available at: http://www. csvr.org.za/docs/correctional/violenceandabuse. pdf, site accessed 8 May 2014.

Human Rights Watch (2010) Unjust and Unhealthy: HIV, TB and Abuse in Zambian Prisons, available at: http://www.hrw.org/reports/2010/04/27/ unjust-andunhealthy-0, site accessed 20 March 2014.

Human Rights Watch (2012) 'Prison is not for me': Arbitrary Detention in South Sudan, available at: http://www.hrw.org/sites/default/files/reports/ southsudan0612ForUpload_1.pdf, site accessed 4 May 2014.

Judicial Inspectorate of Prisons (2004) Women in South African Prisons, A Publication Prepared by the Judicial Inspectorate of Prisons in Support of the 16 Days of Activism Campaign Unite Against Women and Child Abuse, Cape Town.

Jules-Macquet R (2014) The State of South African Prisons, NICRO Public Education Series, Edition One, available at: http://www.nicro.org.za/wpcontent/uploads/2014/04/Public-Education-PaperThe-State-of-South-African-Prisons-2014.pdf, site accessed 2 October 2015. 
Kishor S \& Johnson K (2004) Profiling Domestic Violence - A Multi Country Study, Calverton, Maryland: ORC Macro.

Law Society of Zimbabwe (2013) 'Pre-trial detention in Zimbabwe: Analysis of the Criminal Justice system and conditions of pre-trial detention', available at: http://www.osisa.org/open-learning/ law/zimbabwe/pre-trial-detention-zimbabwe, site accessed 6 April 2014.

Luyt W (2008) 'Imprisoned mothers in South African prisons with children outside of the institution', in European Journal of Crime, Criminal Law and Criminal Justice, 16, 299-323.

Modie-Moroka T (2003) 'Vulnerability across a life course: An empirical study: Women and criminality in Botswana prisons', in Journal of Social Development in Africa, 18, 1, 145-79, available at: http://archive.lib.msu.edu/DMC/African\%20Journals/ pdfs/social\%20development/vol18no1/jsda018001008. pdf, site accessed 8 April 2014.

Nseluke MT \& Siziya S (2013) 'Prevalence and sociodemographic correlates for mental illness among inmates at Lusaka Central Prison, Zambia', in Medical Journal of Zambia, available at: http:// www.mjz.co.zm/content/prevalence-and-sociodemographic-correlates-mental-illness-amonginmates-lusaka-central, site accesed 6 April 2014.

Oketch M (1999) Factors Affecting Female Criminality in Kenya: A Case Study of Langata Maximum Women's Prison, available at: http://researchkenya. or.ke/node/5126, site accessed 24 March 2014.

Open Society Foundations (2013) Socioeconomic Impact of Pre-trial Detention in Ghana, available at: http://www.opensocietyfoundations.org/sites/ default/files/ptd-snapshot-ghana-05232013.pdf, site accessed 1 April 2014.

Open Society Justice Initiative (2011) The Socioeconomic Impact of Pre-Trial Detention, available at: http://www.opensocietyfoundations. org/reports/socioeconomic-impact-pretrial-detention, site accessed 1 April 2014.

Open Society Justice Initiative (2013) The Socioeconomic Impact of Pre-Trial Detention in Sierra Leone, available at: http://www. opensocietyfoundations.org/publications/socioeco nomic-impact-pretrial-detention-sierra-leone, site accessed 1 April 2014.

Pedersen L \& Muntingh L (2010) Assisting the Process of Prison Reform in Southern Sudan: Building Leadership Capacity Within the Prisons Service and Addressing the Circumstances of Prisoners with Specific Needs (Phases I and II), Vienna: United Nations Office on Drugs and Crime.

Pelser E, Burton P \& Gondwe L (2004) Crimes of Need: Results of the Malawi National Crime Victimisation Survey, Institute for Security Studies / Malawi National Statistics Office, available at: http://www. issafrica.org/pubs/Books/CrimesOfNeed/10Points. pdf, site accessed 22 March 2014.

Penal Reform International \& Quaker United Nations Office (2011) 'Briefing on the UN Rules for the Treatment of Women Prisoners and Noncustodial Measures for Women Offenders ('the Bangkok Rules')', available at: http://www. penalreform.org/wp-content/uploads/2013/05/PRI-
QUNO_English_1-1.pdf, site accessed 22 October 2015.

Penal Reform International (2015) 'Global prison trends 2015', available at: http://www.penalreform.org/ wp-content/uploads/2015/04/PRI-Prisons-globaltrends-report-LR.pdf, site accessed 6 November 2015.

Population Council Inc (2008) 'Sexual and gender based violence in Africa: Literature review', available at: http://www.popcouncil.org/uploads/pdfs/ AfricaSGBV_LitReview.pdf, site accessed 7 May 2014.

Republic of Sierra Leone Ministry of Health and Sanitation (2012) 'Mental Health Policy', available at: http://www.whosierraleone.org/1_docs/ mohspartnersdocs/mental_health_policy.pdf, site accessed 6 April 2014.

Sakala JB (1988) 'Women and crime in Zambia', Masters thesis, University of Zambia, available at: 2014 <http://dspace.unza.zm:8080/xmlui/ bitstream/handle/123456789/922/Sakala2JB0001. PDF?sequence=2 and http://dspace.unza.zm:8080/ xmlui/bitstream/handle/123456789/922/SakalaJB 0001.PDF? sequence=1, site accessed 26 March 2014.

Sierra Leone Truth and Reconciliation Commission (2005) Witness to Truth, Chapter 3b Women and the Armed Conflict in Sierra Leone, available at: http://www.sierraleonetrc.org/index.php/viewreport-text-vol-3b/item/volume-three-b-chapterthree?category_id=9, site accessed 29 March 2014.

Sloth-Nielsen J (2005) 'Women and prisons in South Africa', CSPRI Newsletter, No. 9, available at: http://cspri.org.za/publications/newsletter/9\%20-\% 20February\%202005.pdf, site accessed 2 May 2014.

Special Rapporteur on Prisons and Conditions of Detention in Africa (2001) 'Report of the Special Rapporteur on Prisons and Conditions of Detention in Africa: Prisons in Malawi, 17-28 June 2001', available at: http://www.achpr.org/ files/sessions/30th/missionreports/malawi/achpr30_ misrep specmec priso malawi_2001_eng.pdf, site accessed 2 March 2014.

Special Rapporteur on Prisons and Conditions of Detention in Africa (2012) Report presented by Hon. Commissioner Med SK Kaggwa at the 52nd Ordinary Session of the African Commission on Human and Peoples' Rights, 922 October 2012, Cote d'Ivoire, available at: http:// www.achpr.org/files/sessions/52nd/inter-act-reps/ 185/activty_report_prisons_eng.pdf, site accessed 14 November 2015.

Thompson A \& Mahtani S (2012) Women, Debt and Detention: An Exploratory Report on Fraudulent Conversion and the Criminalisation of Debt in Sierra Leone, available at: http://www.advocaidsl. com/wp-content/uploads/2011/03/AdvocAid-WomenDebt-and-Detention-Final-Report.pdf, site accessed 1 April 2014.

Todrys KW \& Amon JJ (2011) 'Health and human rights of women imprisoned in Zambia', in Biomedcentral (BMC) International Health \& Human Rights, available at: http://www.bio medcentral.com/1472-698X/11/8, site accessed 21 March 2014 
Townhead L (2007) 'Pre-trial detention of women and its impact on their children', Women in Prison and Children of Imprisoned Mothers Series, Quaker United Nations Office, available at: http://www. quno.org/resource/2007/2/pre-trial-detention-womenand-its-impact-their-children, site accessed 2 April 2014.

Twea S (2004) 'Women as offenders - the social and legal circumstances of women who commit crimes: A case study of selected prisons in Malawi', Masters Degree, University of Zimbabwe, available at: http://uzweb.uz.ac.zw/ law/women/dissertations/Women\%20criminals\% 20Malawi.pdf, site accessed 2 March 2014.

United Nations (UN) General Assembly (2011) 'Report of the Special Rapporteur on Extreme Poverty and Human Rights' (4 August 2011, A/66/265), available at: http://www.ohchr.org/Documents/lssues/ Poverty/A.66.265.pdf, site accessed 26 May 2014.

United Nations Office on Drugs and Crime (UNODC) (2007) Handbook of Basic Principles and Promising Practices on Alternatives to Imprisonment, available at: http://www.unodc.org/ pdf/criminal_justice/Handbook_of_Basic_Principles_ and Promising Practices on Alternatives to Imprisonment.pdf, site accessed 29 March 2014.

UNODC (2008) Handbook for Prison Managers and Policy Makers on Women and Imprisonment, Criminal Justice Handbook Series, available at: https://www.unodc.org/documents/justice-andprison-reform/women-and-imprisonment.pdf, site accessed 27 February 2014.

UNODC (2011) 'Access to Legal Aid in Criminal Justice Systems in Africa', available at: https://www. unodc.org/pdf/criminal_justice/Survey_Report_on_ Access_to_Legal_Aid_in_Africa.pdf, site accessed 14 November 2015.

UNODC, World Health Organisation (WHO) \& UNAIDS (2006) Prevention, Care, Treatment and Support in Prison Settings, A Framework for an Effective National Response, available at: https://www unodc.org/pdf/HIV-AIDS_prisons_July06.pdf, site accessed 7 May 2014.

UN Special Rapporteur on Violence Against Women (2013) Pathways to, Conditions and Consequences of Incarceration for Women (A) 68/340, 21 August 2013), available at: www. ohchr.org/Documents/lssues/Women/A-68-340. pdf, site accessed 22 February 2014.

UN Women (2011) Progress of the World's Women, available at: http://progress.unwomen.org/pdfs/ EN-Report-Progress.pdf, site accessed 7 May 2014.

United States Department of State (2012) Country Reports on Human Rights Practices 2012 Kenya, available at: http://www.refworld.org/ docid/517e6e1d9.html, site accessed 1 May 2014.

Walmsley R (2015) World Female Imprisonment List, World Prison Brief Database, Third Edition, available at: http://www.prisonstudies.org/sites/ default/files/resources/downloads/world_female_ imprisonment_list_third_edition_0.pdf, site accessed 16 October 2015.

Watson R, Stimpson A \& Hostick T (2004) 'Prison health care: A review of the literature', in
International Journal of Nursing Studies, 41, 2, 119-28.

World Health Organisation (WHO) (2005) WHO Multicountry Study on Women's Health and Domestic Violence against Women: Summary Report of Initial Results on Prevalence, Health Outcomes and Women's Responses, available at: http://www.who.int/gender/violence/who_multi country_study/en/, site accessed 5 May 2014.

WHO (2007a) 'Preventing suicide in jails and prisons', available at: http://www.who.int/mental .../ prevention/suicideresource_jails_prisons.pdf, site accessed 8 May 2014.

WHO (2007b) 'Mental health in prisons', available at: http://www.who.int/mental_health/policy/ legislation/policy/en/, site accessed 10 April 2014.

Zimbabwe National Statistics Agency website (2012a) Zimbabwe Prison Census, 1st Quarter 2012, available at: http://www.zimstat.co.zw/dmdocuments/ Prison/Q1_2012.pdf, site accessed May 2014.

Zimbabwe National Statistics Agency website (2012b) Zimbabwe Prison Census, 2nd Quarter 2012, available at: http://www.zimstat.co.zw/dmdocuments/ Prison/Q2_2012.pdf, site accessed 2 May 2014.

Zimbabwe National Statistics Agency website (2012c) Zimbabwe Prison Census, 3rd Quarter 2012, available at: http://www.zimstat.co.zw/dmdocuments/ Prison/Q3_2012.pdf, site accessed 2 May.

Zimbabwe National Statistics Agency website (2012d) Zimbabwe Prison Census, 4th Quarter 2012, available at: http://www.zimstat.co.zw/dmdocuments/ Prison/Q4_2012.pdf, site accessed 2 May 2014.

\section{International and Domestic Law and \\ Instruments}

African Commission on Human and Peoples' Rights (1979) African Charter on the Rights and Welfare of the Child.

African Committee of Experts on the Rights and Welfare of the Child (2013) General Comment on Article 30 of the Convention on the Rights and Welfare of the Child (ACERWC/GC/01, November 2013).

Department of Correctional Services (2012) Promulgation of Correctional Services Regulations with Amendments Incorporated, Government Gazette 35277, Pretoria.

Laws of Zambia (1996) Prison (Amendment) Act, 1996 Cap 97, Zambia..

Republic of South Africa (1998) Correctional Services Act No 111 of 1998, Pretoria, South Africa.

Republic of South Africa (2011) Correctional Matters Amendment Act No 5 of 2011, Pretoria, South Africa.

United Nations (UN) Economic and Social Council (2010) Official Record, Supplement No. 10, Commission on Crime Prevention and Criminal Justice: Report on the Nineteenth Session (E/ CN.15/2010/30, 4 December 2009 and 17-21 May 2010). 
UN General Assembly (1955) UN Standard Minimum Rules for the Treatment of Prisoners, 30 August 1955.

UN General Assembly (1988) Body of Principles for the Protection of All Persons Under Any Form of Detention or Imprisonment (A/RES/43/173, 9 December 1988).

UN General Assembly (1989) UN Convention on the Rights of the Child (44/25, 20 November 1989).

UN General Assembly (1991) UN Standard Minimum Rules for Non-Custodial Measures (Resolution A/RES/45/110, 2 April 1991).

UN General Assembly (2001) Vienna Declaration on Crime and Justice: Meeting the Challenges of the 21st Century (A/RES/55/59, 17 January 2001).

UN General Assembly (2003) Resolution 58/183 of 22 December 2003.
UN General Assembly (2008) Resolution 63/241 of 24 December 2008.

UN General Assembly (2010) UN Rules for the Treatment of Women Prisoners and Non-custodial Measures for Women Offenders' (A/C.3/65/ L.5, 6 October 2010).

UN General Assembly (2011) Special Rapporteur on Extreme Poverty and Human Rights (Resolution A/66/265, 4 August 2011)

\section{Case Law}

$N$ and Others $v$ Government of Republic of South Africa and Others 2006 (6) SA 543 (D).

$S v M$ (CCT 53/06) [2007] ZACC 18; 2008 (3) SA 232 (CC) (26 September 2007).

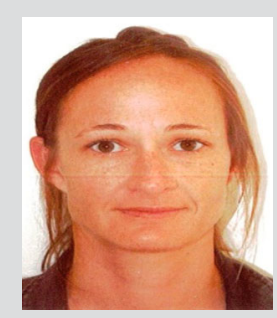

MARILIZE ACKERMANN holds a LLB from the University of Stellenbosch and a LLM from the University of the Western Cape in South Africa. Her fields of professional interests include international human rights law, refugee law, detention and children's rights. Email: marilizeackermann@ hotmail.com 